\title{
Glutamine Synthetase
}

\section{Its Formation in Rat Liver Following Partial Hepatectomy and During Repletion}

\author{
CHUNG WU \\ From the Department of Internal Medicine, The University of Michigan, Ann Arbor, Michigan \\ Received January 22, 1964
}

\begin{abstract}
The change in glutamine synthetase activity has been studied under two conditions of liver growth, namely, mitotic growth after partial hepatectomy and nonmitotic growth during repletion after a fast. The surgical operation caused the enzyme activity in the liver to diminish to one half its normal value within one week after the operation and to remain at this reduced level for the duration of the experiment lasting 90 days. A second partial hepatectomy lowered the synthetase activity still further. The lowering appeared to have resulted from an impairment in the synthesis of the enzyme, which was associated with the high mitotic activity of the liver, and presumably with the de novo synthesis of deoxyribonucleic acid. Furthermore, partial hepatectomy did not affect the kidney enzyme, nor did unilateral nephrectomy decrease the liver enzyme.

A temporary fall in the liver synthetase activity resulted from repleting after a fast; the fall depended on the diet of repletion, being greater on a low protein diet than on a high protein diet. Conversely, the kidney enzyme of the rat during repletion rose to a. higher level on a low protein diet than on a high protein diet.

Raising the glutamine content in the diet did not reduce the synthetase activity in rat liver, nor did omitting glutamine from the diet increase the enzyme activity. A protein-free diet, however, proved to be more detrimental to the enzyme in liver than fasting, which brought varied effects on the enzyme depending on its duration.
\end{abstract}

\section{INTRODUCTION}

The preceding paper of this series (1) concerns the study of glutamine synthetase in the rapidly dividing liver cells of developing rats. The present report describes the formation of the enzyme in the liver cells of adult rats made to divide or to grow rapidly by means of partial hepatectomy or repletion after a fast. It also provides information to assess the different effects of these two procedures on the enzyme.

A number of enzymes have been studied in rat liver following partial hepatectomy. Some of these enzymes showed an increase in activity in the regenerating liver, such as alkaline phosphatase (2), thymidine kinase (3), and carbamyl phosphate-aspartate transcarbamylase (4). Others exhibited a decrease in activity, such as uracil reductase
(5) and aldolase (6). Still others remained unchanged, such as deoxyadenosine kinase (7). In those instances where an increase or a decrease in activity occurred, the enzyme activity invariably returned to the normal level when the regenerating process ceased.

Nonmitotic liver growth takes place during repletion after a fast. Duration of fasting and of repleting, and composition of the diet used in repleting the animal would certainly affect the activity of an enzyme in the growing liver. The effect of repletion on several enzymes in carbohydrate and amino acid metabolism (8-10) has been studied in the rat liver.

Whereas both hepatectomy and repletion can bring about liver growth, they entail some notable differences. Surgery removes the lobes at once and in their entirety, 
creating an altered blood flow through the organ without due compensation for lowered metabolic activities in other parts of the body. Recently, however, Alston and Thomson (11) have shown that the rise in portal blood pressure following partial hepatectomy lasted only a few hours. On the other hand, fasting diminishes gradually the liver mass as a whole with concurrent decrease in the metabolic activity of the entire organism. Furthermore, the chemical composition of the liver cell of a fasted rat (12) is different from that of the remnant lobes of a hepatectomized rat, which is normal before regeneration begins.

\section{EXPERIMENTAL PROCEDURE}

Male rats of the Sprague-Dawley strain weighing 300-400 gm served as the surgical subjects for partial hepatectomy. The operation was carried out according to the technique of Higgins and Anderson (13), and it removed about $70 \%$ of the liver. The animals were killed at various intervals of time after the operation. In another series of experiments, the animals underwent a second partial hepatectomy. This was done as follows: A second incision about $3 \mathrm{~cm}$ long was made about one $\mathrm{cm}$ to the right of the mid-line and immediately below the last rib. This opening exposed the right lateral lobe, which was ligated and excised. The surgery removed about $60 \%$ of the liver which had undergone regeneration. After the second operation, the animal had only the caudate lobe left. This lobe was allowed to regenerate for a second time. The same post-operative care was taken after the second surgery as was after the first. But the mortality rate following the second partial hepatectony reached $44 \%$, compared with $3 \%$ following the first operation. The lobes removed during the first partial hepatectomy served for determining the enzyme activity in normal liver; those taken during the second partial hepatectomy and at death yielded values for the enzyme activity in regenerating liver.

Unilateral nephrectomy was done through an incision in the flank of the rat. These animals had body weights similar to those used in the partial hepatectomy experiments.

Male rats of the Wistar strain weighing about $300 \mathrm{gm}$ served in all experiments pertaining to fasting and refeeding. During the period of repletion the animals received diets containing variable amounts of casein. 'The diet containing $25 \%$ casein has been described elsewhere (14). The protein content of the diet was varied at the expense of the carbohydrate. A diet in which $36 \%$ of an acid hydrolyzate of casein $(8.1 \% \mathrm{~N}, 38.5 \%$ salt; Nutritional Biochemicals Corporation) replaced casein, and supplemented with $0.1 \%$ tryptophan, served as the glutamine-free diet. Because of the high salt content of this diet, the animals receiving it drank large volumes of water and urinated excessively; they also lost weight averaging $2 \mathrm{gm}$ per day.

A procedure described in detail previously (15) served to assay glutamine synthetase activity. But a modification of the color development procedure was introduced to increase the color intensity of the hydroxamic acid- $\mathrm{FeCl}_{3}$ complex. At the end of the incubation time, into $4.5 \mathrm{ml}$ of the reaction mixture was added $0.5 \mathrm{ml}$ of a reagent containing per $100 \mathrm{ml}, 45 \mathrm{gm}$ trichloroacetic acid, $46 \mathrm{ml}$ concentrated $\mathrm{HCl}$, and $8.3 \mathrm{gm} \mathrm{FeCl}_{3} \cdot 6 \mathrm{H}_{2} \mathrm{O}$. The filtrate served for the color measurement. The unit for expressing glutamine synthetase activity has been defined (1).

The method of Lowry et al. (16) served for determining the protein. Glutamine was determined as before (15).

\section{RESULTS}

Figure 1 shows the fall of glutamine synthetase activity in rat liver following partial hepatectomy. For each animal, the enzyme activity (units per gram of liver) of the regenerating or regenerated liver is expressed as a percentage of that found in the lobes removed during the operation, which served as the control. The animals received a laboratory chow at all times. The rate of decrease in the activity appeared to be the highest during the first day, after which the enzyme activity continued to fall until the seventh day when it reached the lowest point. The enzyme activity remained at this level, about $50 \%$ of its normal value, throughout the entire experimental period of 90 days when the observations ended. In two similar experiments, the animals received a $75 \%$ casein diet or a glutamine-free diet, but neither one of these two diets seemed to have any effect on the fall of the liver enzyme during liver regeneration. On the other hand, feeding the hepatectomized rats with a low protein diet intensified the lowering of the enzyme activity. According to Higgins and Anderson (13), the rate of liver restoration was the grealest in 48 to 72 hours following partial hepatectomy, and the restoration was completed in 14 to 21 days. Apparently, the liver did not regain 


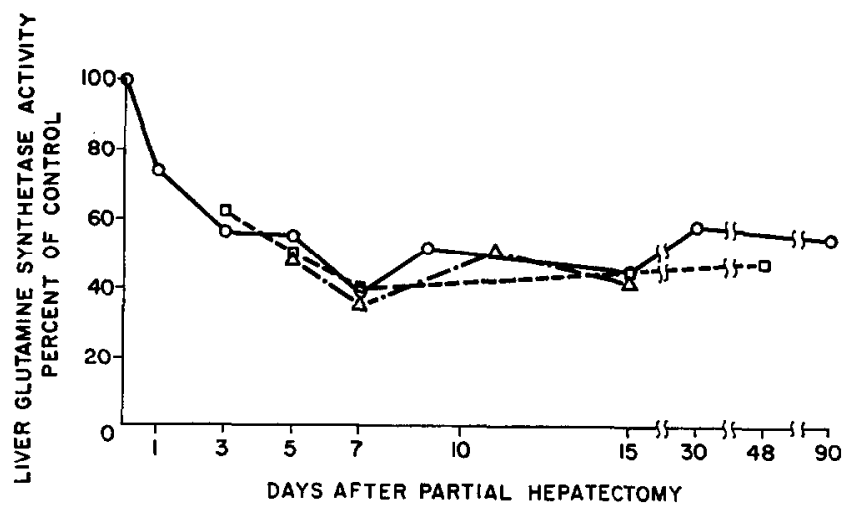

Fig. 1. The lowering of glutamine synthetase activity in rat liver after partial hepatectomy. The hepatectomized rats received a laboratory chow (O), a $75 \%$ casein diet ( $\square$ ), or a glutamine-free $\operatorname{diet}(\triangle)$. Each point represents the average from 3 to 5 rats.

TABLE I

Further Decrease in Liver Glutamine Synthetase Activity Following a Second Partial Hepatectomy

Male Sprague-Dawley rats weighing 300-400 gm underwent a second partial hepatectomy 3-90 days following the first operation. The animals received a laboratory chow and were killed 5-59 days after the second operation. The lobes removed during the first and the second operations, and at sacrifice, served for determining the enzyme activity. The difference between any two of the three sets of the activity data shown in the table is significant by the $t$ test at a $5 \%$ level.

\begin{tabular}{ccccccc}
\hline \multirow{2}{*}{$\begin{array}{c}\text { Number } \\
\text { of rats }\end{array}$} & $\begin{array}{c}\text { Initial activity } \\
\text { (units/gm) }\end{array}$ & \multicolumn{2}{c}{ First operation } & & \multicolumn{2}{c}{ Second operation } \\
& $181 \pm 42^{a}$ & $\begin{array}{c}\text { Activity } \\
\text { (units/gm) }\end{array}$ & $\begin{array}{c}\text { \% of initial } \\
\text { activity }\end{array}$ & & $\begin{array}{c}\text { Activity } \\
\text { (units/gm) }\end{array}$ & $\begin{array}{c}\% \text { of initial } \\
\text { activity }\end{array}$ \\
\hline 12 & $181.2 \pm 30.9$ & 53.7 & & $63.0 \pm 15.7$ & 34.8 \\
\hline
\end{tabular}

${ }^{a}$ In this and in all following tables, the value preceded by the \pm sign is the standard deviation from the mean.

the enzyme activity for a long time after it had fully regenerated. Therefore, as far as glutamine synthetase is concerned, a liver that has undergone regeneration is no longer a normal liver.

A further decrease in the enzyme activity can be demonstrated in rats undergoing partial hepatectomy for the second time. Table I summarizes the results. Although animals living for various lengths of time after the operation were used, no correlation seemed to exist between the decrease in the enzyme activity in liver and the duration of the post-operative period. Hence, the values obtained from these animals were treated as a group and averaged. The extent of the fall in the enzyme activity following partial hepatectomy varied from one animal to another, but in every animal the liver enzyme dropped to an even lower level follow- ing the second operation than it did after the first. $\mathrm{A}$ few animals were allowed to live for 30 to 60 days after the second surgery; the enzyme activity remained at low levels despite a full restoration of the liver mass.

The concentration of free glutamine in the liver that had undergone regeneration for various periods of time was not significantly different from that of normal liver. The result indicates that either the decreased synthetase activity was sufficient to maintain a normal level of glutamine in the regenerating liver, or the enzyme activity in other organs (15) contributed to the maintenance of the glutamine level in the liver.

A previous study has shown that the intracellular distribution of glutamine synthetase in the regenerating liver resembled that of normal liver (17). The result indicates that various subcellular structures of 
TABLE II

Glutamine Synthetase Activity in Rat Liver and Kidney Following Partial Hepatectomy and Unilateral Nephrectomy

Male Sprague-Dawley rats weighing about $300 \mathrm{gm}$ served as the surgical subjects. Hepatectomized rats were killed from 1 to 90 days after operation; nephrectomized rats were killed about 90 days after operation.

\begin{tabular}{lll}
\hline \multicolumn{1}{c}{ Surgical operation } & Liver (units/gm) & Kidney (units/gm) \\
\hline None & $228.0 \pm 40.4(55)^{a}$ & $88.4 \pm 14.8(5)$ \\
Partial hepatectomy & $118.0 \pm 34.0(55)$ & $90.0^{b} \pm 16.0(8)$ \\
Unilateral nephrectomy & $197.2^{b} \pm 45.6(8)$ & $62.8^{b} \pm 14.0(8)$ \\
\hline
\end{tabular}

a The number of animals used.

${ }^{b}$ Not significantly different from the control by the $t$ test at a 0.05 level.

the regenerating liver shared proportionally the loss of the enzyme, and that the loss did not take place preferentially in any one structure.

The observations described above raise the question whether the loss of the enzvme activity resulted from the surgical operation per se or from the regeneration process. The results in Table II show that partial hepatectomy lowered the activity of the liver enzyme but not that of the kidney enzyme, whereas unilateral nephrectomy did not significantly decrease the enzyme activity in either the remaining kidney or the liver. Surgical operation per se appeared to be incapable of inducing a loss of the enzyme in an organ. The loss occurred, however, only in the organ undergoing or having undergone rapid mitosis as a result of the surgery.

Combining a homogenate of normal liver with that of regenerating liver always yielded an enzyme activity equal to the summed activities of the two homogenates. The result indicates that the lowered activity in the regenerating liver did not arise from an inhibition and suggests that the formation of the enzyme proceeded at a reduced rate in the regenerating liver.

We may now examine the situation from a different angle, namely, under conditions where nonmitotic liver growth is induced by prior fasting to reduce the liver mass. Since the change in the enzyme activity during repletion with different diets will be examined, we may first consider the dietary effect on the enzyme.

Table III shows that the enzyme activity

\section{TABLE III}

Effect of Different Diets on Glutamine Synthetase Activity in Rat Liver

Five to 10 Sprague-Dawley male rats weighing about $300 \mathrm{gm}$ at the beginning of each experiment received the spccificd diet for the number of days shown.

\begin{tabular}{l|r|c|c|c}
\hline \multicolumn{1}{c|}{ Ditl } & $\begin{array}{c}\text { Days } \\
\text { on diet }\end{array}$ & $\begin{array}{c}\text { Enzyme activity } \\
\text { (units/gm })\end{array}$ & $\begin{array}{c}\text { Free glutamine } \\
(\mu \text { moles/gm) }\end{array}$ \\
\hline $25 \%$ Casein & 28 & $203.6 \pm 26.8$ & 5.7 & \pm 0.6 \\
$75 \%$ Casein & 15 & $185.2^{a} \pm 34.4$ & & \\
$0 \%$ Casein & 14 & $72.4 \pm 20.4$ & & \\
Glutamine-free & 9 & $156.8^{b} \pm 21.6$ & $6.1^{a} \pm 0.6$ \\
$18 \%$ Casein + & $10-12$ & $182.8^{a} \pm 18.0$ & $7.5 \pm 1.1$ \\
$7 \%$ glutamine & & & & \\
\hline
\end{tabular}

${ }^{a}$ Not significantly different from the control ( $25 \%$ casein) by the $t$ test at a 0.05 level.

${ }^{b}$ The significant drop may result from a general effect due to the high salt content of this diet. See text.

was decreased in the liver of rats fed a protein-free diet. A high protein diet did not, however, affect the enzyme activity. Inclusion of $7 \%$ glutamine in the diet also resulted in no change in the enzyme activity. Hence, in the rat, glutamine synthetase is not repressible by glutamine given either orally or intraperitoneally (1). Receiving the glutamine-free diet failed to raise the synthetase level in the liver of the rat. This result is consistent with the inability of the high glutamine diet to lower the enzyme activity. The liver glutamine content of rats fed the glutamine-free diet was, however, normal.

Figure 2 shows the changes in glutamine 


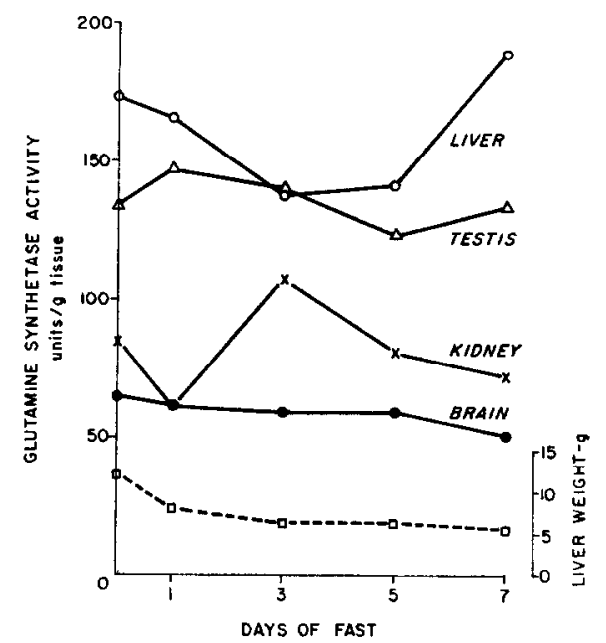

FIG. 2. Changes in glutamine synthetase activity in rat liver $(\mathrm{O}-\mathrm{O})$, testis $(\triangle-\Delta)$, kidney $(X-X)$, and brain ( $-O$ ) during a 7 -day fast. Each point represents the average from 6 rats. The standard deviations from the mean values for the liver after $0,1,3,5$, and 7 days of fast were $26.0,19.6,13.6,9.6$, and 46.8 , respectively; those for the kidney were $4.4,11.2,8.8$, 14.8 , and 10.4 , respectively.

synthetase activity in the liver, testis, kidney, and brain of the rat during a fast. Fasting had little detrimental effect on the enzyme in the brain and testis. In the liver, however, a decrease in the enzyme activity occurred during the early stages of fasting, indicating that the loss of the enzyme proceeded at a higher rate than that of other constituents in the tissue. But prolonged fasting reversed this trend. By the seventh day of fast, the liver showed an enzyme activity slightly exceeding that before the fast. Since in a 7-day fast, the nitrogen content per unit weight of liver increased by only $10-20 \%$ (18), the activity curve in units per milligram of protein would have essentially the same shape as that in units per gram of liver (Fig. 2). But in the same period of fasting, the number of nuclei per unit weight of liver has doubled (18). Therefore, although the enzyme activily per gram of liver on the seventh day of fast equalled that of the control, the activity per nucleus [per cell or per unit weight of deoxyribonucleic acid (DNA)] was actually halved.

The change in the kidney appeared to be just the opposite. The kidney attained its highest level of the synthetase activity on the third day of fast, when the liver had its lowest level of activity.

Because of the changes observed in the liver and kidney as a result of fasting, the formation of glutamine synthetase during repletion was followed in these two organs. The animals were fasted for 5 days, by which time the liver had lost about $50 \%$ of its original weight (Fig. 2), while the loss in kidney weight amounted to only 10-20\%. At the end of the 5-day fast, the animals received a diet containing 5,25 , or $75 \%$ casein for various lengths of time. Table IV

TABLE IV

Effect on Liver Weight and Liver Protein Content of Repletion on Three Different

Diets Following a Five-Day Fast IN THE RAT

Each group consisted of 5 male Wistar rats weighing $295 \pm 23 \mathrm{gm}$ at the beginning of the experiment. After a 5 -day fast, their body weights decreased to $230 \pm 24 \mathrm{gm}$. On repletion the animals regained their original weights in 6 days with the $25 \%$ casein diet and in 10 days with the $75 \%$ casein diet. The body weights of the animals repleted with the $5 \%$ casein diet remained at about $82 \%$ of their original weights up to and including 10 days. The change in liver weight during fasting, i.e., before repletion, is shown in Fig. 2.

\begin{tabular}{|c|c|c|c|}
\hline $\begin{array}{c}\text { Days of } \\
\text { repletion }\end{array}$ & $\begin{array}{l}\text { Casein in } \\
\operatorname{diet}(\%)\end{array}$ & $\begin{array}{l}\text { Liver weight } \\
\text { after repletion } \\
\quad(\mathrm{gm})\end{array}$ & $\begin{array}{c}\text { Liver protein } \\
\text { after repletion } \\
\text { (mg/100 mg liver) }\end{array}$ \\
\hline 1 & $\begin{array}{r}5 \\
25 \\
75\end{array}$ & $\begin{array}{r}9.8 \pm 0.9 \\
12.1 \pm 2.1 \\
8.5 \pm 1.3\end{array}$ & $\begin{array}{l}17.8 \pm 1.5 \\
18.8 \pm 0.2 \\
22.9 \pm 1.8\end{array}$ \\
\hline 3 & $\begin{array}{r}5 \\
25 \\
75\end{array}$ & $\begin{array}{r}10.9 \pm 1.8 \\
15.6 \pm 2.7 \\
9.9 \pm 1.6\end{array}$ & $\begin{array}{l}16.6 \pm 1.3 \\
20.8 \pm 1.1 \\
27.5 \pm 2.6\end{array}$ \\
\hline 6 & $\begin{array}{r}5 \\
25 \\
75\end{array}$ & $\begin{array}{r}8.4 \pm 1.0 \\
12.8 \pm 2.9 \\
12.4 \pm 0.8\end{array}$ & $\begin{array}{l}20.5 \pm 2.3 \\
22.8 \pm 0.2 \\
25.8 \pm 2.2\end{array}$ \\
\hline 10 & $\begin{array}{r}5 \\
25 \\
75\end{array}$ & $\begin{array}{r}9.5 \pm 1.8 \\
12.8 \pm 1.1 \\
12.3 \pm 1.1\end{array}$ & $\begin{array}{l}19.4 \pm 2.4 \\
22.6 \pm 1.7 \\
26.3 \pm 2.2\end{array}$ \\
\hline 23 & $\begin{array}{l}25 \\
75\end{array}$ & $\begin{array}{l}13.7 \pm 1.9 \\
13.2 \pm 1.2\end{array}$ & $\begin{array}{l}26.3 \pm 2.6 \\
32.2 \pm 1.7\end{array}$ \\
\hline
\end{tabular}


lists the changes in liver weight and liver protein in rats receiving these diets. The animals regained their lost liver weights faster on the $25 \%$ casein diet than on either the 5 or the $75 \%$ casein diet. In fact, the liver nearly attained its prefasting weight after repletion on the $25 \%$ casein diet for one day. The protein content in the liver of roplcting rats, however, clearly reflected the protein content of the diet. These results have confirmed and extended the findings reported many years ago by Addis et al (19).

Glutamine synthetase activity in the liver during repletion on the three diets is shown in units per gram of liver in Fig. 3. The enzyme activity fell as soon as the repletion began. This may be contrasted to an elevation of the activity if fasting had been permitted to continue, as shown in Fig. 2. The extent of the initial decline in the enzyme activity depended on the protein content. of the diet; the fall was to a lesser extent, with a higher protein diet. In addition, the initial drop in the enzyme activity occurred concomitantly with the rapid regain in the liver weight on repletion (Table IV).

Animals fed the $25 \%$ casein diet regained their body weights in 6 days and liver weights in onc day after the repletion began (Table IV), but the enzyme activity in the liver of these rats remained below the prefasting level after 10 days of repleting (H'ig. 3). Although the enzyme activity eventually returned to the control level after repleting for 23 days (data not shown), these results, nevertheless, suggest that, in the course of repletion, the synthesis of the enzyme in rat liver lagged behind that of other hepatic constituents, including liver protein in general.

Combination of the results shown in Table IV and in Fig. 3 permits calculation of the enzyme activity in terms of units per liver and units per milligram of protein for rats repleted with the three diets. When expressed in units per liver, the enzyme activity in rats repleted with the $5 \%$ casein diet showed a progressive decline with time. Comparison of the $25 \%$ casein diet with the $75 \%$ casein diet shows that the increase in the total activity in the liver was greater with the $25 \%$ casein diet during the first 3 days of reple-

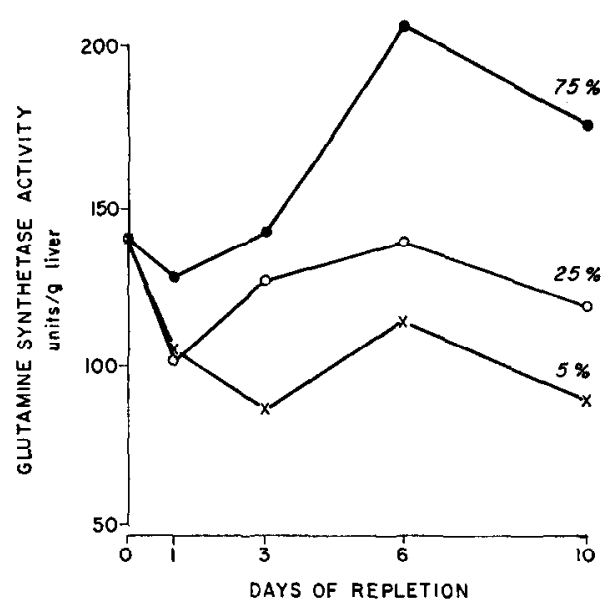

FIg. 3. Changes in glutamine synthetase activity in rat liver during repletion on $5 \%$ casein $(X-X), 25 \%$ casein $(0-0)$, or $75 \%$ casein (O-O) diet after a 5-day fast. The standard deviations from the mean values after repleting for $1,3,6$, and 10 days on $5 \%$ casein diet were 7.3 , $10.0,26.0$, and 16.1 , respectively; those on $25 \%$ casein diet were $4.0,26.0,14.4$, and 17.2 , respectively; and those on $75 \%$ casein diet were 10.8 , $18.0,12.2$, and 10.0 , respectively.

tion, after that, the $75 \%$ casein diet yielded a much higher total activity in the liver. The specific activity of the enzyme in the liver of rats repleted with the 5,25 , and $75 \%$ casein diets for one to 10 days averaged, respectively, $0.49,0.56$, and 0.71 units per milligram of protein. Hence, with the higher protein diet, the specific activity of the enzyme was also higher, indicating that the rate of synthesis of the enzyme exceeded that of other proteins. Previous results have, however, shown that the high protein diet did not alter the liver enzyme in rats not subjected to prior fasting (Table III), nor alleviate the fall of the liver enzyme in hepatectomized rats (Fig. 1).

In contrast to the findings in liver, a low protein diet appeared to be more beneficial to the formation of glutamine synthetase in kidney of the repleting rat. The results listed in Table $V$ demonstrate two points: First, in each of the two expressions used for the enzyme activity, the $5 \%$ casein diet yielded higher values than did the 25 or the $75 \%$ casein diet. Second, repleting on the latter two diets lowered the enzyme activity progressively with the duration of the experi- 
TABLE V

Effect of Repletion with Different Djets on Glutamine Synthetase Activity in Rax Kidney

\begin{tabular}{|c|c|c|c|c|c|c|}
\hline \multirow{3}{*}{$\begin{array}{l}\text { Days of } \\
\text { repletion }\end{array}$} & \multicolumn{6}{|c|}{ Glutamine synthetase activity } \\
\hline & \multicolumn{2}{|c|}{$5 \%$ Casein } & \multicolumn{2}{|c|}{$25 \%$ Casein $^{a}$} & \multicolumn{2}{|c|}{$75 \%$ Casein } \\
\hline & $\begin{array}{l}\text { Units/mg } \\
\text { protein }\end{array}$ & $\begin{array}{l}\text { Units/gm } \\
\text { kidney }\end{array}$ & $\begin{array}{l}\text { Units/mg } \\
\text { protein }\end{array}$ & $\begin{array}{c}\text { Units/gm } \\
\text { kidney }\end{array}$ & $\begin{array}{c}\text { Units/mg } \\
\text { protein }\end{array}$ & $\begin{array}{l}\text { Units/gm } \\
\text { kidney }\end{array}$ \\
\hline 1 & $0.42 \pm 0.07$ & $100 \pm 7$ & $0.40 \pm 0.06$ & $85.6 \pm 8.4$ & $0.32 \pm 0.04$ & $74.8 \pm 6.7$ \\
\hline 3 & $0.46 \pm 0.07$ & $104 \pm 24$ & $0.32 \pm 0.05$ & $74.9 \pm 4.4$ & $0.28 \pm 0.04$ & $66.8 \pm 8.6$ \\
\hline 6 & $0.49 \pm 0.04$ & $104 \pm 4$ & $0.31 \pm 0.03$ & $68.2 \pm 13.4$ & $0.38 \pm 0.05$ & $84.4 \pm 3.6$ \\
\hline 10 & $0.46 \pm 0.04$ & $104 \pm 10$ & $0.20 \pm 0.04$ & $44.4 \pm 7.6$ & $0.31 \pm 0.02$ & $72.4 \pm 8.0$ \\
\hline 23 & & & $0.29 \pm 0.04$ & $48.8 \pm 17.0$ & $0.19 \pm 0.03$ & $49.2 \pm 21.0$ \\
\hline
\end{tabular}

a The values for normal rats (without prior fasting) on this diet were $0.39 \pm 0.02$ units per milligram of protein and $85.7 \pm 14.9$ units per gram of kidney.

ment. In these respects, the formation of the enzyme in the kidney and in the liver of the repleting rat differed.

\section{DISCUSSION}

One of the chief differences in the hepatic composition between hepatectomized and fasted rats lies in the DNA content. Liver regeneration following partial hepatectomy involves a multiplication of cell population $\rightarrow$ a de novo synthesis of the entire cellular constituents including DNA. Liver growth during repletion consists mainly in the replenishment of cytoplasmic constituents but not of DNA, since the number of cells and the DNA content in the liver remained unaltered during a fast (18). As we have seen in this study, partial hepatectomy resulted in a lasting decrease in glutamine synthetase, whereas fasting-repleting produced only a transient reduction. Evidence presented suggests that the concentration of the enzyme is lower in the liver of hepatectomized rats than in that of normal rats. But the possibility that the liver of hepatectomized rats synthesizes a less active enzyme also exists.

The question raised in the present study is not only why the enzyme activity was decreased during liver regeneration, but why the decrease persisted for a long time after the regeneration had completed. If the decrease results from an impairment of glutamine synthetase forming system, caused by or associated with the rapid mitosis and, hence, the de novo synthesis of DNA, the impairment appears to be an inherent de- fect, not only of the rapidly dividing cells, but also of the future generations of these cells. Moreover, the impairment can be aggravated by a subsequent rapid mitosis, since a second partial hepatectomy brought about a further lowering of the enzyme activity. It may be noted also that the highest rate of the lowering of glutamine synthetase activity shown in this study and the highest rate of DNA synthesis (20) occurred at about the same time- -24 hours after partial hepatectomy. The preceding paper (1) has reported that inhibitors of DNA synthesis could increase the synthetase activity in the liver of developing rats but not in the liver of adult rats. Results to be presented in a subsequent communication have shown that the Novikoff and the several Morris hepatomas, in contrast to normal liver, had negligible or very low glutamine synthetase activity. Although these results lend support to the idea of an inverse relationship of the formation of glutamine synthetase to DNA synthesis, evidence to this effect has not been obtained. Hence, it would be unwarranted to exclude other possibilities at this time.

Tsuboi et al. (21) have observed a certain marked deficiency in the number of nuclei restored in the fully regenerated mouse liver following partial hepatectomy. This abnormality probably occurs also in the regenerated rat liver and, if so, may be related to the lowering of the enzyme activity.

The maintenance of the enzyme activity at a high level in the kidney of rats repleted 
on a low protein diet and the lowering of its activity on a high protein diet would indicate that the formation of glutamine synthetase in this tissue has been proceeding at the maximal rate on the $5 \%$ casein diet. A higher protein diet permits the synthesis of other cellular constituents at a higher rate but not that of the enzyme, thus resulting in a fall of the specific activity of the enzyme. This view implies that, in the repleting rat, the synthesis of the enzyme in the kidney has the first priority to that of most other proteins.

Glutamine synthetase activity decreased in the liver of rats fed a protein-free diet but not in the liver of rats subjected to prolonged fasting. Schimke (22) has made a similar observation with urea cycle enzymes in rat liver. Although glutamine synthetase does not directly participate in the synthesis of urea, nevertheless, it plays an efficient role in the removal of ammonia from the system in the rat (23). The return of the enzyme activity to the normal level in the 7 day-fasted rat may constitute an adaptive measure to combat ammonia poisoning, since the animal derived its energy chiefly from the breakdown of tissue proteins.

The enzyme in liver, kidney, brain, and testis of the rat responded differently to fasting. The brain enzyme appears to be lcast affected by metabolic alterations. A previous study with developing rats has also demonstrated this point (1). In addition, although the enzyme activity in liver of tumor-bearing rats fell below the normal level (24), the enzyme activity in brain did not. ${ }^{1}$

The liver glutamine synthetase of an intact rat could not be repressed by a high glutamine diet and was not increased by a glutamine-free diet. In mammalian cell cultures, however, De Mars (25), and Paul and Fottrell (26) have shown the inhibition of glutamyltransferase by glutamine and the increase in the enzyme activity upon withdrawal of glutamine.

\section{ACKNOWLEDGMENTS}

The author wishes to acknowledge the technical assistance of Mr. Euriel H. Roberts.

The work was supported in part by research

1 Unpublished observation. grants, CA-01719 and AM-07319, from the National Cancer Institute and the National Institute of Arthritis and Metabolic Diseases, U. S. Public Health Service.

\section{REFERENCES}

1. Wu, C., Arch. Biochem. Biophys. 106, 394 (1964).

2. Oppenheimer, M. J., and Flock, E. V., Am. J. Physiol. 149, 418 (1947).

3. Bollem, F. J., A ND Potter, V. R., Cancer Res. 19, 561 (1959).

4. Calva, E., and Cohen, P. P., Cancer Res. 19, 679 (1959).

5. Fritzson, P., J. Biol. Chem. 237, 150 (1962).

6. Sánchez, Q. E., Soberón, G., Palacios, O., Lee, E., and Kuri, M., J. Biol. Chem. 236, 1607 (1961).

7. Beltz, R. E., Arch. Biochem. Biophys. 99, 304 (1962).

8. Niemeyer, H., González, C., and Rozzi, R., J. Biol. Chem. 236, 610 (1961).

9. Soberón, G., and Sánchez, Q. E., J. Biol. Chem. 236, 1602 (1961).

10. Weber, G., and MacDonatd, H., Exptl. Cell Res. 22, 292 (1961).

11. Alston, W. C., and Thomson, R. Y.. Cancer Res. 23, 901 (1963).

12. Harrison, M. F., Biochem.J. 55, 204 (1953).

13. Higgins, G. M., and Anderson, R. M.. Arrh. Pathol. 12, 186 (1981).

14. Wu, C., and BaUer, J. M., Cancer Res. 22. 1239 (1962).

15. Wu, C., Comp. Biochem. Physiol. 8, 335 (1963).

16. Lowry, O. H., Rosebrough, N. J., Farr, A. L., and Randalt, R. J., J. Biol. Chem. 193. 265 (1951).

17. Wu, C., Biochim. Biophys. Acta 77, 482 (1963).

18. Allard, C., de Lamirande, G., ani) Cantero, A., Exptl. Cell Res. 13, 69 (1957).

19. Addis, T., Poo, L. J., and Lew, W., J. Biol. Chem. 116, 343 (1936).

20. Bucher, N. L. R., Bourne, G. II., and Danielli, J. F., Intern. Rev. Cytol. 15, 245 (1963).

21. Tsubor, K. K., Yokoyama, H. O., Stuweill, R. E., and Wilson, M. E., Arch. Biochem. Biophys. 48, 275 (1954).

22. Sснике, R. T., J. Biol. Chem. 237, 1921 (1962).

23. Duda, G. D., and Handegr, P., J. Biol. Chem. 232, 303 (1958).

24. Wu, C., AND BAUer, J. M., Cancer Res. 20, 848 (1960).

25. De Mars, R., Biochim. Biophys. Acta 27, 435 (1958).

26. Paul, J., and Fottrell, P. F., Biochim. Biophys. Acta 67, 334 (1963). 